\title{
Quantification and mitigation of nitrogen leaching in a maize silage cropping system
}

\author{
R. TSIMBA ${ }^{1 *}$, T.D. GUNN ${ }^{1}$, R.J. DENSLEY ${ }^{2}$, J.A. MILLAR ${ }^{1}$, I.D. WILLIAMS ${ }^{1}$, G.O. EDMEADES ${ }^{3}$ \\ ${ }^{1}$ Genetic Technologies Limited, PO Box 105303, Auckland 1143, NZ; \\ ${ }^{2}$ Tomorrows Solutions, 86B Highden Rd, RDI, Te Awamutu 3879, NZ; \\ ${ }^{3} 19 B$ Shadbolt Dr, Cambridge. \\ * Corresponding author rtsimba@genetic.co.nz
}

\begin{abstract}
Lysimeters and suction cups were used to measure total $\mathrm{N}$ leaching in a high $\mathrm{N}$ maize crop system in the Waikato, grown in sequence with a ryegrass catch crop (RG) or left fallow in 2018/19 and 2019/20 growing seasons. This study determined appropriate depth for measuring leaching under maize $(0.70$ or $1.2 \mathrm{~m}$ depth). At least $200 \mathrm{~kg} / \mathrm{ha}$ more fertiliser $\mathrm{N}$ than the calculated requirements was applied to the maize to ensure surplus levels. Greatest losses were observed in the fallow rotation, averaging $60 \mathrm{~kg} \mathrm{~N} / \mathrm{ha}$ and 88 $\mathrm{kg} \mathrm{N} / \mathrm{ha}$ for either season, respectively, despite a drier winter. Greater leaching in 2019/20 was attributed to higher soil $\mathrm{N}$ concentration $(+15 \mathrm{mg} \mathrm{N} / \mathrm{l})$ in 2020 . Including RG reduced leaching by $>85 \%$, and took up at least $200 \mathrm{~kg} \mathrm{~N} / \mathrm{ha}$. Less than $10 \%$ leaching occurred during maize growing. Losses at $70 \mathrm{~cm}$ soil depth were almost three times higher than $120 \mathrm{~cm}$. Similar amounts of isotopic ${ }^{15} \mathrm{~N}(1.2 \%)$ were observed in maize grain when applied at $70 \mathrm{~cm}$ or $120 \mathrm{~cm}$ depth. Background levels, when urea was applied, was $0.37 \%$. Provided applied fertiliser rates match crop demand, $\mathrm{N}$ leaching losses from maize crops should be lower than values reported here.
\end{abstract}

Keywords: maize, ryegrass, fallow, soil depth

\section{Introduction}

Nitrogen $(\mathrm{N})$ can be considered as one of the most critical nutrients for crop growth. However, if not properly managed, $\mathrm{N}$ leaching from cropping can significantly impact groundwater quality. In some countries, limits on crop fertiliser $\mathrm{N}$ inputs have been implemented (Cassman and Dobermann, 2021). The challenge with this approach is that it does not consider $\mathrm{N}$ fertiliser use efficiency at a farm level.

A large amount of $\mathrm{N}$ is required to optimise maize production and application rates should vary according to crop yield potential. For instance, a $16 \mathrm{tDM} /$ ha silage crop can remove up to $200 \mathrm{~kg} \mathrm{~N} / \mathrm{ha}$ compared to $250 \mathrm{~kg}$ $\mathrm{N} /$ ha for a $20 \mathrm{t} \mathrm{DM} /$ ha crop. Maize yields are impacted by weather, particularly under rainfed conditions, yet nutrient application rate decisions are generally made early in the season. Most parts of New Zealand, including the upper and lower parts of the North Island and the upper east coast of the South Island tend to be in soil moisture deficit between December and February (NIWA, 2021), the main growing period for maize. Nitrogen leaching risk during this time is, therefore, minimal. The potential for leaching losses is greater in winter, especially if there is excess soil N. Total applied $\mathrm{N}$ should take into account the background soil levels. Quantification and proper management of surplus soil $\mathrm{N}$ after maize harvest is therefore a prerequisite to developing mitigation strategies to reduce $\mathrm{N}$ leaching losses in maize systems.

Unlike pasture, maize is a deep-rooted crop with an effective rooting depth of $150-180 \mathrm{~cm}$ in unimpeded soils (Kovacs et al., 1995; Grignani et al., 2007). This allows it to capture $\mathrm{N}$ and water from greater depths than pasture (Kristensen and Thorup-Kristensen 2004). Results from $\mathrm{N}$ leaching studies under maize crops in New Zealand have been variable. In a winter fallow situation, Betteridge et al. (2007) reported losses of 220 $\mathrm{kg} \mathrm{N} / \mathrm{ha}$ when measurements were conducted at a 60 $\mathrm{cm}$ depth on a pumice soil. Elsewhere, on a Paparua silt loam soil, Beare et al. (2010) recorded $>70 \mathrm{~kg} \mathrm{~N} / \mathrm{ha}$ or $53 \mathrm{~kg} \mathrm{~N} / \mathrm{ha}$ when measurements were taken at a $60 \mathrm{~cm}$ or $150 \mathrm{~cm}$ soil depth, respectively, in a maize-winter cropping sequence.

Non-legume winter-active crops can be used as an effective tool to reduce $\mathrm{N}$ leaching during winter (Meisinger, 1991; Grignani et al., 2007). Fraser et al. (2010) recorded leaching reductions of 76 to $119 \mathrm{~kg} \mathrm{~N} / \mathrm{ha}$ when summer crops were followed by winter catch crops, relative to fallow. Similar results have been reported in other studies (FAR 2006; Malcolm et al., 2016).

The objectives of the following study were to: 1) quantify the potential $\mathrm{N}$ leaching losses under a longterm maize plus a cut and carry winter crop system; 2) determine an appropriate depth for measuring $\mathrm{N}$ leaching losses under maize and 3) determine the impact of a catch crop on mitigating $\mathrm{N}$ leaching losses after maize silage harvest.

\section{Materials and methods}

A field experiment was carried out on an allophanic soil near Te Awamutu (37057'07'S; 175'14'47'; 40 m asl). 
Prior to the experiment, the paddock had been in a longterm maize silage/winter annual ryegrass $(\mathrm{RG})$ rotation. The research involves three independent, but related experiments, each a completely randomised block design with four replications. Rainfall and temperature data collected from the site were supplemented with long-term data from Hamilton Airport, located $16 \mathrm{~km}$ North East of the experimental site (Table 1).

\section{Experiment 1}

On the $27^{\text {th }}$ of October 2018 and $29^{\text {th }}$ of October 2019, a Pioneer maize hybrid, P1253, with a comparative relative maturity (CRM) of 109 , was seeded at 110,000 plants/ha in eight four-row plots (11.5 m x $3 \mathrm{~m})$, using a precision planter. Prior to planting, composite soil sampling was conducted to $15 \mathrm{~cm}$ depth across the experimental area to determine fertiliser requirement. Fertiliser and other management details can be found in Tsimba et al. (2020). In brief, all nutrients and lime applications, other than $\mathrm{N}$, were based on the soil test result and paddock yield potential. Nitrogen was applied at about $400 \mathrm{~kg} \mathrm{~N} / \mathrm{ha}$ to allow for surplus $\mathrm{N}$ after maize harvest.

Throughout the year, $\mathrm{NO}_{3}-\mathrm{N}$ and $\mathrm{NH}_{4}+-\mathrm{N}$ leaching losses were measured at $120 \mathrm{~cm}$ soil depth using an array of six $50 \mathrm{~cm}$ diameter $\mathrm{x} 120 \mathrm{~cm}$ high barrel lysimeters to estimate drainage, and four ceramic suction cup samplers that were spaced $2.5 \mathrm{~m}$ apart within each plot to measure nitrate concentration of the drained soil water. For simplicity, although leaching values reported in this study included $\mathrm{NO}_{3}^{-}-\mathrm{N}$ and $\mathrm{NH}_{4}^{+}-\mathrm{N}$, leaching was referred to simply as $\mathrm{N}$. Each suction cup sampler was attached to a collection bottle through tubes buried $50 \mathrm{~cm}$ below the soil surface. The bottles were centrally located in watertight boxes and connected to a vacuum pump, which delivered a uniform vacuum across all bottles, enabling constant withdrawal of ground water whenever drainage occurred. The lysimeters drained into 51 containers connected to their base through tubes. Once drainage was registered, the vacuum pump was triggered to initiate suction cup sampling, and the volume of water in the containers was measured using a graduated measuring cylinder.

When above ground maize biomass reached an estimated 35\% dry matter content (26 March 2019 and 24 March 2020), two centre rows from each plot were harvested as silage using a two-row, small plot Wintersteiger silage chopper. Dry matter and N content were measured using a calibrated Near Infrared Spectroscopy (NIRS) system mounted on the chopper. A tetraploid annual ryegrass cultivar was then immediately direct drilled into four of the eight harvested maize plots at a rate of $30 \mathrm{~kg} / \mathrm{ha}$. No $\mathrm{N}$ fertiliser was added to the $\mathrm{RG}$, because the purpose of experiment was to measure efficiency of RG in taking up left-over $\mathrm{N}$ after maize. The remaining plots were left fallow. When the RG reached about $30 \mathrm{~cm}$ height, two $0.5 \mathrm{~m} \mathrm{x} 10 \mathrm{~m}$ strips were cut, using a push lawn mower, cutting to $5 \mathrm{~cm}$ height, and weighed. Two $1 \mathrm{~kg}$ subsamples were sent to the laboratory for $\mathrm{N}$ and gravimetric DM analyses.

\section{Experiment 2}

Twelve pairs of suction cups spaced $2.5 \mathrm{~m}$ apart were installed in four plots, consisting of fallow and RG

Table 1 Total monthly rainfalls and average monthly mean temperatures for 2018/19, 2019/20 and 1999 - 2019 seasons for Hamilton Airport.

\begin{tabular}{|c|c|c|c|c|c|c|}
\hline & \multicolumn{3}{|c|}{ Monthly total rainfall (mm) } & \multicolumn{3}{|c|}{ Monthly mean temperature $\left({ }^{\circ} \mathrm{C}\right)$} \\
\hline & 2018/19 & 2019/20 & 1999-2019 & 2018/19 & $2019 / 20$ & 1999-2019 \\
\hline October & 73 & 68 & 104 & 12.6 & 13.2 & 13.0 \\
\hline November & 96 & 44 & 87 & 14.4 & 14.3 & 14.5 \\
\hline December & 179 & 59 & 108 & 18.1 & 17.9 & 17.2 \\
\hline January & 32 & 9 & 87 & 19.7 & 18.3 & 18.5 \\
\hline February & 18 & 18 & 87 & 19.8 & 19.9 & 19.1 \\
\hline March & 41 & 74 & 74 & 19.0 & 17.0 & 17.4 \\
\hline April & 78 & 76 & 98 & 13.9 & 14.5 & 14.8 \\
\hline May & 45 & 73 & 118 & 12.4 & 11.3 & 12.1 \\
\hline June & 100 & 109 & 124 & 9.1 & 11.1 & 9.7 \\
\hline July & 119 & 112 & 128 & 10.0 & 9.2 & 8.9 \\
\hline August & 128 & 114 & 113 & 10.3 & 10.4 & 9.8 \\
\hline September & 121 & 71 & 113 & 11.5 & 11.4 & 11.6 \\
\hline Annual & 1030 & 828 & 1241 & 14.2 & 14.0 & 13.9 \\
\hline
\end{tabular}


treatments. Each pair consisted of one cup installed at $70 \mathrm{~cm}$ depth and another one at right angles and $50 \mathrm{~cm}$ directly below the first. This experiment was designed to compare $\mathrm{N}$ leaching losses at $70 \mathrm{~cm}$ (standard depth generally used to measure $\mathrm{N}$ leaching) and $120 \mathrm{~cm}$ (assumed maximum effective rooting depth of maize across a range of environments). As in Experiment 1, six barrel lysimeters with $50 \mathrm{~cm}$ diameter and at $70 \mathrm{~cm}$ depth were installed to measure drainage. Leachate and drainage measurements were conducted at the same time as in Experiment 1.

\section{Experiment 3}

A maize study using ${ }^{15} \mathrm{~N}$ was conducted in spring 2020 to determine the effectiveness of uptake by maize roots. The experiment consisted of three ${ }^{15} \mathrm{~N}$ enriched treatments and a control. Plot area consisted of three rows, sized $2.3 \mathrm{~m}$ wide x $2 \mathrm{~m}$ long. Each row consisted of 15-16 evenly spaced maize plants sown at a density of 100,000 plants/ha. At planting, $40 \mathrm{~kg} \mathrm{~N} / \mathrm{ha}$ was applied as starter fertiliser in the form of diammonium phosphate $(17.6 \% \mathrm{~N})$. At approximately V6 maize development stage, urea $(46 \% \mathrm{~N})$ was broadcast at a rate of $75 \mathrm{~kg} \mathrm{~N} / \mathrm{ha}$. Within a week of urea application, $30 \mathrm{~kg} \mathrm{~N} / \mathrm{ha}$ in the form of liquid $\mathrm{KNO}_{3}$ enriched with ${ }^{15} \mathrm{~N}\left(5 \%\right.$ as $\left.{ }^{15} \mathrm{~N}\right)$ was injected via a modified $8 \mathrm{~mm}$ diameter stainless steel pipe to a depth of $60 \mathrm{~cm}, 90$ $\mathrm{cm}$ or $120 \mathrm{~cm}$ under each plant within the centre row of each treatment plot (Hodgen et al., 2009). Urea at an equivalence of $30 \mathrm{~kg} \mathrm{~N} / \mathrm{ha}$ was broadcast on the centre row of the control plots at the same time. Ten consecutive buffered plants within the $2 \mathrm{~m}$ plot were clearly marked for future sampling to trace ${ }^{15} \mathrm{~N}$ uptake.

Approximately 2-4 weeks after physiological maturity (black layer) ears were removed from the treated plants for drying to constant weight in a forced air oven. Leaves and husks were removed and stored into paper bags for air drying. The stalks were then cut at approximately $10 \mathrm{~cm}$ above ground level, chopped into smaller sections and split for rapid air drying in paper bags. Samples from the individual plant components (leaf, stalk and grain) were ground to $2 \mathrm{~mm}$ screen size in a Wiley ${ }^{\circledR}$ mill, and then to 100 -mesh screen fineness with a roller mill (Arnold and Schepers, 2004) that was cleaned with ethanol between plots. Total $\mathrm{N}$ and isotopic $\mathrm{N}$ composition of plant samples were analysed at the UC Davis Stable Isotope Facility using an automated combustion elemental analyser interfaced with a continuous-flow isotope ratio mass spectrometer.

\section{Statistical analysis}

Statistical analyses were performed using Genstat version 21 (VSN International 2019). Differences in catch crop $\mathrm{N}$ uptake and leaching losses were subjected to analysis of variance (ANOVA). The StudentNewman-Keuls test was used to test the significance of differences between treatment means $(\mathrm{P} \leq 0.05)$.

\section{Results}

\section{Weather, crop dry matter yields and $\mathrm{N}$ uptake}

The average total rainfall during the 2019/20 maize growing season (October - March) was half the Waikato long term average $(550 \mathrm{~mm})$ and $40 \%$ less than that in 2018/19 (Table 1). The June to September rainfall totals for $2018 / 19$ and $2019 / 20$ were $2 \%$ and $15 \%$ lower than the Waikato long-term average, respectively.

Table 2 summarises the maize silage dry matter (DM) yields and $\mathrm{N}$ uptake for the maize-RG and maize-fallow (control) catch crop options. In 2019/20, maize had lower DM yields and less $\mathrm{N}$ uptake in plots that were fallowed the previous winter, compared to those in RG.

With RG, despite the significant DM yield differences

Table 2 Maize silage dry matter yields and nitrogen uptake for 2018/19 and 2019/20 seasons in Te Awamutu.

\begin{tabular}{|c|c|c|c|c|}
\hline & \multicolumn{2}{|c|}{ Maize Silage Yield t DM/ha) } & \multicolumn{2}{|c|}{ Maize $\mathrm{N}$ uptake $(\mathrm{kg} / \mathrm{ha})$} \\
\hline & Control & $\mathbf{R G}$ & Control & RG \\
\hline $2018 / 19$ & 27.5 & 27.2 & 321.4 & 301.9 \\
\hline $2019 / 20$ & 23.6 & 25.2 & 141.5 & 207.8 \\
\hline \multirow[t]{2}{*}{ Standard error of mean } & \multicolumn{2}{|c|}{0.645} & \multicolumn{2}{|c|}{20.68} \\
\hline & \multicolumn{2}{|c|}{ P-value } & & \\
\hline Season & \multicolumn{2}{|c|}{ * } & \multicolumn{2}{|c|}{ * } \\
\hline Catch crop & \multicolumn{2}{|c|}{ NS } & \multicolumn{2}{|c|}{ NS } \\
\hline Catch crop*season & \multicolumn{2}{|c|}{ NS } & \multicolumn{2}{|c|}{ * } \\
\hline
\end{tabular}

RG, Annual ryegrass;

Catch crop refers to the winter crop treatment following maize (i.e., RG or fallow);

NS, not significant;

* indicates difference significant at $\mathrm{P} \leq 0.05$. 
between the two seasons (Table 3), the difference in total $\mathrm{N}$ uptake between the years was not significant.

\section{Nitrate-nitrogen leaching}

Nitrate-N leaching losses were much higher in the maize-fallow than the maize-RG catch crop plots (Table 4). Whereas leaching losses in fallow plots were greater in 2019/20 than 2018/19, the opposite occurred in the RG catch crop plots.

The nitrate concentrations for the 2019/20 leachate samples from fallow plots were, on average, $15 \mathrm{mg}$ $\mathrm{N} / 1$ higher than the previous season (Figure 1). Plots with $\mathrm{RG}$ growing over winter had significantly lower $\mathrm{N}$ concentrations in both seasons.

\section{Comparison of leaching losses measured at different soil depths}

For both seasons, leaching losses were significantly greater when collected at $70 \mathrm{~cm}$ than $120 \mathrm{~cm}$, but only in the maize-fallow rotation plots. The average $\mathrm{N}$ concentration was significantly greater at $70 \mathrm{~cm}$ than $120 \mathrm{~cm}$ for the fallow plots (Table 4).

Table 3

Total annual dry matter yield and total nitrogen uptake by annual ryegrass during 2018/19 and 2019/20 crop seasons in Te Awamutu.

\begin{tabular}{lcc}
\hline & DM yield (t/ha) & N uptake $(\mathbf{k g} / \mathbf{h a})$ \\
\hline $2018 / 19$ & $5.4 \mathrm{a}$ & $215.2 \mathrm{a}$ \\
$2019 / 20$ & $7.4 \mathrm{~b}$ & $235.2 \mathrm{a}$ \\
\hline
\end{tabular}

Values with a different letter within a column are statistically different $(P \leq 0.05)$.

Table 4 Nitrate- $N$ leaching losses $( \pm 1$ SEM) in a maize$R G$ and maize-fallow rotation (control) in 2018/19 and 2019/20 crop seasons (April - October) in Te Awamutu.

\begin{tabular}{lcc}
\hline & \multicolumn{2}{c}{ N leaching (kg/ha) } \\
\cline { 2 - 3 } & Control & RG \\
\hline $2018 / 19$ & $59.6 \pm 11.65$ & $8.8 \pm 2.96$ \\
$2019 / 20$ & $88.4 \pm 9.10$ & $0.31 \pm 0.04$ \\
\hline \multicolumn{3}{c}{ P-value } \\
\hline \multirow{3}{*}{ Season } & NS \\
Catch crop & $*$ \\
Catch crop & \multicolumn{2}{c}{ *year } \\
\hline
\end{tabular}

RG, Annual ryegrass;

Catch crop refers to the winter crop treatment (i.e., RG or control);

NS, not significant;

${ }^{*}$, means significantly different at $\mathrm{P}<0.05$

\section{Efficacy of $\mathbf{N}$ uptake at depth}

Measurements of isotopic ${ }^{15} \mathrm{~N}$ abundance in maize plant components after maturity showed evidence of $\mathrm{N}$ uptake from roots at $120 \mathrm{~cm}$ soil depth (Table 6). While the leaf component had less ${ }^{15} \mathrm{~N}$ at the $90 \mathrm{~cm}$ and 120 $\mathrm{cm}$ depths than at $60 \mathrm{~cm}$, there was no difference in both maize stalks and grain.

\section{Discussion}

At about $550 \mathrm{~mm}$, the long-term Waikato average season rainfall during the maize growing season was just sufficient to grow a good maize crop without irrigation. If rainfall is less than crop requirement or fails to coincide with demand, supplementation from soil water residual reserves is necessary. Growing conditions in New Zealand, where evapotranspiration usually exceeds rainfall in summer, mean that leaching largely occurs in winter, when rainfall exceeds evapotranspiration rates (Di and Cameron, 2002). During the June to September period, hereafter referred to as winter, rainfall is not only important for recharging soil water reserves after summer but has the largest impact on $\mathrm{N}$ leaching losses. Despite the 2020 winter being much drier with less soil water drainage than 2019, N leaching in the fallow plots was greater, because $\mathrm{N}$ concentrations in soil water were higher than in 2019. The lower total rainfall for

Table 5 Total nitrate-N leaching losses and concentration when measured at $70 \mathrm{~cm}$ and $120 \mathrm{~cm}$ below the soil surface during the 2018/19 and 2019/20 seasons.

\begin{tabular}{lllllll}
\hline & \multicolumn{2}{c}{$\begin{array}{c}\text { Leaching losses, } \\
\text { kg N/ha }\end{array}$} & & \multicolumn{2}{c}{$\begin{array}{c}\text { N concentration } \\
\text { mg/L }\end{array}$} \\
\cline { 2 - 3 } \cline { 5 - 6 } & Control & RG & & Control & RG \\
\hline $70 \mathrm{~cm}$ & $119.2 \mathrm{a}$ & $5.93 \mathrm{c}$ & & $51.92 \mathrm{a}$ & $2.88 \mathrm{c}$ \\
$120 \mathrm{~cm}$ & $41.6 \mathrm{~b}$ & $2.18 \mathrm{c}$ & & $21.74 \mathrm{~b}$ & $1.49 \mathrm{c}$ \\
\hline
\end{tabular}

RG, Annual ryegrass;

Values with a different letter are statistically different $(P \leq 0.05)$.

Table 6 Percentage of ${ }^{15} \mathrm{~N}$ recovered in maize leaves, stalks and grain from labelled $\mathrm{KNO}_{3}$ applied at 60 $\mathrm{cm}, 90 \mathrm{~cm}$ and $120 \mathrm{~cm}$ soil depth, compared to control during the 2019/20 season.

\begin{tabular}{lccc}
\hline Depth $(\mathbf{c m})$ & Leaf & Stalks & Grain \\
\hline 0 & $0.37 \mathrm{a}$ & $0.37 \mathrm{a}$ & $0.37 \mathrm{a}$ \\
60 & $0.72 \mathrm{~b}$ & $0.82 \mathrm{~b}$ & $1.07 \mathrm{~b}$ \\
90 & $0.71 \mathrm{bc}$ & $0.92 \mathrm{~b}$ & $1.31 \mathrm{~b}$ \\
120 & $0.54 \mathrm{c}$ & $0.96 \mathrm{~b}$ & $1.21 \mathrm{~b}$ \\
\hline
\end{tabular}

Values with a different letter within the table are statistically different $(P \leq 0.05)$. 


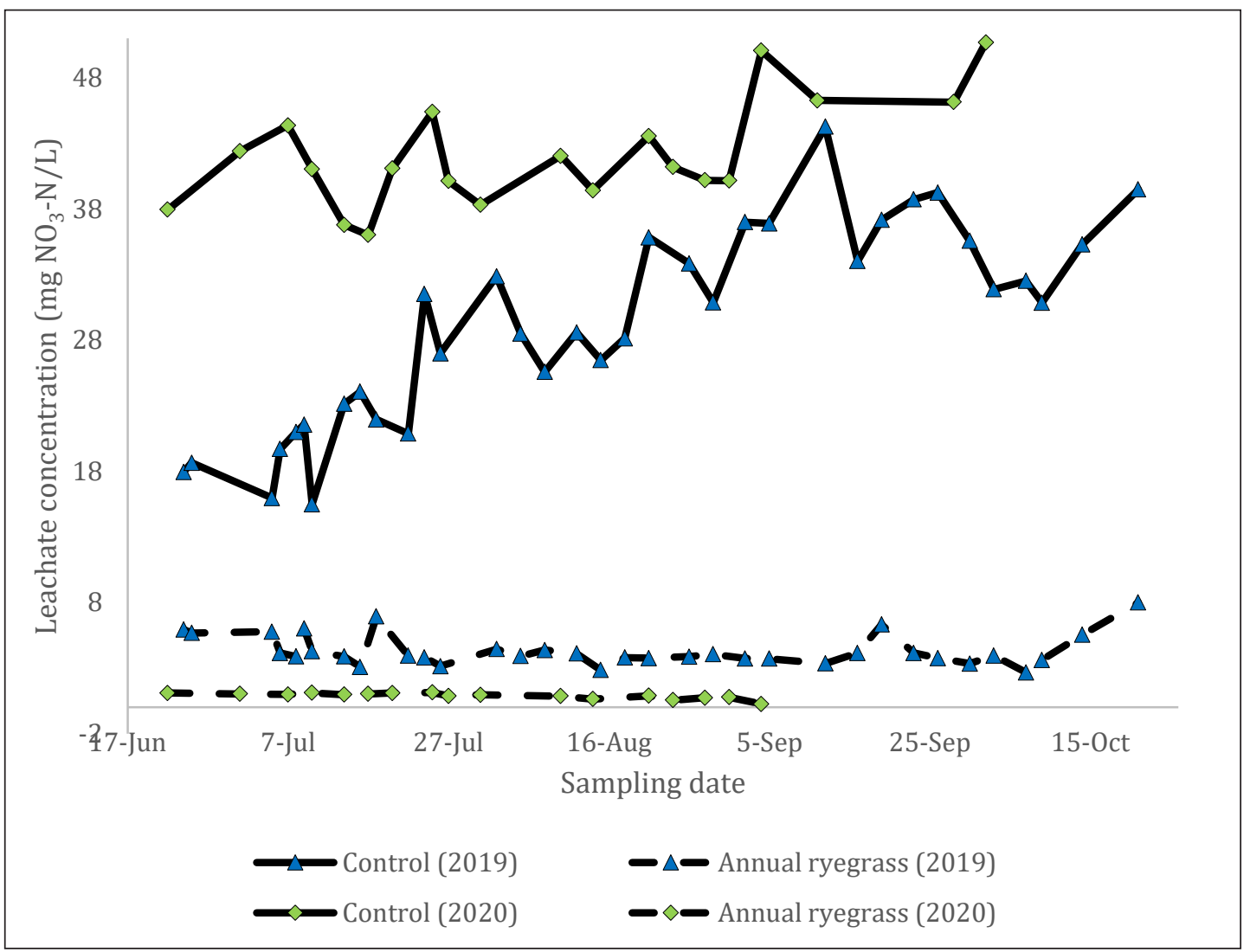

Figure 1 Nitrate- $\mathrm{N}$ concentrations for leachate samples collected at the $120 \mathrm{~cm}$ soil depth at a Te Awamutu site during the $2018 / 19$ (2019) and 2019/20 (2020) seasons.

2019/20 reduced maize silage yield and corresponding $\mathrm{N}$ uptake, increasing leaching risk due to surplus soil levels. There was $160 \mathrm{~kg}$ more soil $\mathrm{N} / \mathrm{ha}$ in the top $120 \mathrm{~cm}$ soil profile going into winter for 2019/20 than for the 2018/19 season (data not shown). Surplus N is one of the key indicators for determining $\mathrm{N}$ leaching risk (Ross et al., 2008). The key to mitigating leaching appears to be the ability to capture the surplus $\mathrm{N}$ before it escapes beyond the rooting depth.

The importance of catch crops after maize cannot be overstated. Over the two years of this study, growing RG over winter resulted in $\mathrm{N}$ leaching reductions of $>85 \%$. Similar results have been reported by other workers for other crops, such as forage kale (Brassica oleracea L.; Carey et al., 2016; 2017). Not only was RG effective at reducing $\mathrm{N}$ leaching, but it improved soil water storage. Gravimetric soil moisture measurements immediately after maize silage harvest showed a $7.3 \%$ greater moisture content in the top $30 \mathrm{~cm}$ for the annual RG than fallow plots (data not shown). This could explain the greater maize DM yields and $\mathrm{N}$ uptake in RG plots than seen in the previously fallowed plots for 2019/20. Soils after winter cropping tend to have improved soil infiltration, which results in more available soil water (Frye et al., 1988; Basche et al., 2016).

In relative terms, the differences in DM maize yields between years was much smaller $(10 \%)$ than maize $\mathrm{N}$ uptake $(40 \%)$. This observation was consistent with 'luxury' N uptake seen in 2018/19. Luxury N uptake beyond requirement for maximum biomass production is common in maize, and acts as a buffer against potential $\mathrm{N}$ stresses occurring during grain-fill (Plénet and Lemaire. 2000; Ciampitti and Vyn, 2012; Nasielski et al., 2019) as observed in 2019/20.

In contrast with maize, the DM yield difference in $R G$ between the two seasons was much greater than differences in $\mathrm{N}$ uptake. This indicated potential luxury $\mathrm{N}$ uptake in $2018 / 19$. Unlike RG, which grows vegetatively, maize is capable of remobilising the excess $\mathrm{N}$ towards the growing ear, reducing the total plant $\mathrm{N}$ relative to DM yield. Though largely influenced by growth rate, plant $\mathrm{N}$ content and biomass for vegetative crops are not linear, with $\mathrm{N}$ uptake declining as the plants get bigger and percentage $\mathrm{N}$ getting less over time. (Angus and Moncur, 1985; Greenwood et al., 1990). 
Despite high $\mathrm{N}$ fertiliser rates applied in this study ( $>200 \mathrm{~kg} \mathrm{~N} / \mathrm{ha}$ above maize plant requirements), total leaching losses were much lower than the $220 \mathrm{~kg} \mathrm{~N} /$ ha reported by Betteridge et al. (2007) for pumice soil. In a simulation experiment conducted under similar conditions to the current study, Zyskowski et al. (2016) reported much higher leaching losses (187 kg N/ha) than those recorded in this study. This may be because measurements were at $120 \mathrm{~cm}$ instead of the $60 \mathrm{~cm}$ used by Betteridge et al. (2007). Less than $10 \%$ of the leaching losses were recorded during the maize growing season.

The high $\mathrm{N}$ fertiliser rates used in this study were to ensure surplus soil $\mathrm{N}$ after maize cropping in order to quantify the effectiveness of the RG catch-crop in mitigating $\mathrm{N}$ leaching losses. Leaching under a typical maize cropping system using the recommended amount of $\mathrm{N}$ fertiliser should have been much lower than the values obtained. Leaching is a function of $\mathrm{N}$ concentration and the volume of water that drains below a prescribed rooting depth, considered to be $120 \mathrm{~cm}$ in this study. Leaching measurements at shallower depths can significantly overestimate $\mathrm{N}$ losses. This was evident in the current research, where losses at $70 \mathrm{~cm}$ were three times greater than at $120 \mathrm{~cm}$. Beare et al. (2010) reported similar findings. Maize is a deep-rooted crop, capable of extracting nutrients from a depth of up to $1.8 \mathrm{~m}$ (Kovacs et al., 1995; FAR, 2006; Grignani et al., 2007). Not all soil conditions will allow maize roots to reach such a depth, hence the choice of $120 \mathrm{~cm}$ was a default root depth.

On average, drainage measured at $70 \mathrm{~cm}$ was about $25 \%$ greater than at $120 \mathrm{~cm}$. Greater leaching losses at $70 \mathrm{~cm}$ in fallow plots could be attributed to higher drainage. Additionally, $\mathrm{N}$ concentration at $70 \mathrm{~cm}$ was more than double compared to $120 \mathrm{~cm}$, especially in fallow situations. It is clear that significant uptake of $\mathrm{N}$ and water occurred between $70 \mathrm{~cm}$ and $120 \mathrm{~cm}$ depth, which was consistent with Jamieson et al. (1995) who reported $\mathrm{N}$ extraction depth of about $1.5 \mathrm{~m}$. Where $\mathrm{RG}$ was grown over winter, $\mathrm{N}$ concentration was significantly lower, reducing leaching risk.

Nitrogen ${ }^{15}$ isotope was traced in both maize grain and stalks, irrespective of depth of placement, which demonstrated that roots grew to $120 \mathrm{~cm}$ or beyond and were capable of extracting $\mathrm{N}$ at depth. The lower ${ }^{15} \mathrm{~N}$ concentrations in maize leaves at $120 \mathrm{~cm}$ could have been due to $\mathrm{N}$ partitioning between the ear and leaves, particularly during a dry season like 2019/20. Maize generally remobilises $45-65 \%$ of the $\mathrm{N}$ in grain from other plant parts (Ciampitti and Vyn, 2012; Ning et al., 2017). Under stress conditions, if the plant is not capable of extracting enough soil nutrients to support grain-fill, leaves will likely be the first organs to show deficiency, which is consistent with observations of foliar $\mathrm{N}$ deficiency under drought (G. Edmeades, pers. comm., 2021).

\section{Conclusions}

Despite fertiliser rate having a direct influence on $\mathrm{N}$ leaching, actual losses can be modified by better crop management. Establishing a catch crop after maize was found to largely mitigate $\mathrm{N}$ leaching through increased uptake, and reduction of soil concentrations and water losses through transpiration, which impacted soil drainage volumes. Despite the high $\mathrm{N}$ fertiliser input for the maize crop, total $\mathrm{N}$ leaching losses, even in the absence of a catch crop, were not as high as has been reported in other New Zealand studies. For growers applying the appropriate amount of fertiliser, $\mathrm{N}$ leaching losses should be much lower than the results seen in this study.

When reporting $\mathrm{N}$ leaching losses in maize, it is critical that the correct depth is used, otherwise losses are likely to be overstated. The ability to trace ${ }^{15} \mathrm{~N}$ isotope applied at different depths showed maize was capable of extracting $\mathrm{N}$ at $120 \mathrm{~cm}$ depth. The evidence for the ability of catch crops to mitigate $\mathrm{N}$ leaching was convincing. In addition, this approach appeared to improve infiltration and moisture retention, particularly in the drier season.

\section{REFERENCES}

Angus J F, Moncur MW. 1985. Models of growth and development of wheat in relation to plant nitrogen. Australian Journal of Agricultural Research 36: 537-544. https://doi.org/10.1071/AR9850537

Arnold SL, Schepers JS. 2004. A Simple Roller-Mill Grinding Procedure for Plant and Soil Samples. Communications in Soil Science and Plant Analysis 35: 537-545. https://doi:10.1081/CSS-120029730.

Basche AD, Kaspar TC, Archontoulis SV, Jaynes DB, Sauer T, Parkin TB, Miguez FE. 2016. Soil water improvements with the long-term use of a winter rye cover crop. Agricultural Water Management 172: 4050. https://doi.org/10.1016/j.agwat.2016.04.006

Beare MH, Tabley F, Gillespie R, Maley S, HarrisonKirk T, de Ruiter J. 2010. Nitrate leaching from high production forage crop sequences. Proceedings of the New Zealand Grassland Association 72: 23-28. https://doi.org/10.33584/jnzg.2010.72.2812

Betteridge K, Hoogendoorn CJ, Thorrold, BS, Costall, Ledgard, ZA, Park-ng, Theobald PW. 2007. Nitrate leaching and productivity of some farming options in the Lake Taupo catchment. Proceedings of the New Zealand Grassland Association 69: 123-129. https:// doi.org/10.33584/jnzg.2007.69.2677

Carey P, Cameron K, Di H, Edwards G. 2017. Comparison of nitrate leaching from oats and Italian ryegrass catch crops following simulated winter forage grazing: a field lysimeter study. New Zealand Journal of Agricultural Research 60: 298-318. https://doi.org/10.1080/00288233.2017.1336103 
Carey PL, Cameron KC, Di HJ, Edwards GR, Chapman DF. 2016. Sowing a winter catch crop can reduce nitrate leaching losses from winter-applied urine under simulated forage grazing: a lysimeter study. Soil Use and Management 32: 329-337. https://doi. org/10.1111/sum.12276

Cassman KG, Dobermann A. 2021. Nitrogen and the future of agriculture: 20 years on. Ambio 31: 132140. https://doi.org/10.1007/s13280-021-01526-w.

Ciampitti IA, Vyn TJ. 2012. Physiological perspectives of changes over time in maize yield dependency on nitrogen uptake and associated nitrogen efficiencies: a review. Field Crops Research. 133: 48-67. https:// doi.org/10.1016/j.fcr.2012.03.008

Di HJ, Cameron KC. 2002. Nitrate leaching in temperate agroecosystems: sources, factors and mitigating strategies. Nutrient Cycling in Agroecosystems 64: 237-256. https://doi. org/10.1023/A:1021471531188

FAR (Foundation for Arable Research). 2006. No. 36. Early leaching of nitrate in maize paddocks. https:// www.far.org.nz/assets/files/uploads/36Mz_Early_ Season_Leaching.pdf

Fraser PM, Harrison-Kirk T, Tabley F, Meenken ED, Beare MH, Curtin D, Gillespie RN, Francis GS. 2010. Cover crops and tillage intensity affect nitrate leaching. Agronomy New Zealand 40: 43-49. https:// www.cabdirect.org/cabdirect/abstract/20143056224

Frye WW, Blevins RL, Smith MS, Corak SJ, Varco JJ. 1988. Role of annual legume cover crops in efficient use of water and nitrogen pp. 129-154. In: Hargrove WL. Eds. Cropping Strategies for Efficient Use of Water and Nitrogen. ASA Special Publication 51, American Society of Agronomy, Inc., Crop Science Society of America, Inc., Madison, WI. https://doi. org/10.2134/asaspecpub51.c8

Greenwood DJ, Lemaire G, Gosse G, Cruz P, Draycott A, Neeteson JJ. 1990. Decline in percentage N of $\mathrm{C}_{3}$ and $\mathrm{C}_{4}$ crops with increasing plant mass. Annals of Botany 66: 425-436. https://doi.org/10.1093/ oxfordjournals.aob.a088044

Grignani C, Zavattoro L, Sacco D, Monaco S. 2007. Production, nitrogen and carbon balance of maize based forage systems. European Journal of Agronomy 26: 442-453. https://doi.org/10.1016/j. eja.2007.01.005

Hodgen PJ, Ferguson RB, Shanahan JF, Schepers JS. 2009.Uptake of point source depleted ${ }^{15} \mathrm{~N}$ fertilizer by neighboring corn plants. Agronomy Journal 101:1-7. https://dx.doi.org/10.2134/agronj2008.0186

Jamieson PD, Martin RJ, Francis, GS. 1995. Drought influences on grain yield of barley, wheat, and maize. New Zealand Journal of Crop and Horticultural Science 23: 55-66. https://doi.org/10.1080/0114067 1.1995 .9513868
Kovacs GJ, Nemeth T, Ritchie JT. 1995. Testing simulation models for the assessment of crop production and nitrate leaching in Hungary. $13 \mathrm{pp}$. https://doi.org/10.1016/0308-521X(95)00032-Z

Kristensen HL, Thorup-Kristensen K. 2004. Root growth and nitrate uptake of three different catch crops in deep soil layers. Soil Science Society of America Journal, 68: 529-537. https://doi. org/10.2136/sssaj2004.5290

Malcolm B, Teixeira E, Johnstone P, Maley S, de Ruiter J, Chakwizira E. 2016. Catch crops after winter grazing for production and environmental benefits. Agronomy New Zealand 46: 99-108. https://www. agronomysociety.nz/files/2016_10._Catch_crops_ after_winter_grazing.pdf

Meisinger JJ, Hargrove WL, Mikkelsen RL, Williams JR, Benson, VW. 1991. Effects of cover crops on groundwater quality. pp. 57-68, In W. L. Hargrove (ed.), Cover Crops for Clean Water: Proc. Intl. Conference. Soil and Water Conservation Society of America. Ankeny, IA. https://www.swcs.org/static/ media/cms/CCCW4ground_D30E9A7F53D56.pdf

Nasielski J, Earl H, Deen B. 2019. Luxury vegetative nitrogen uptake in maize buffers grain yield under post-silking water and nitrogen stress: a mechanistic understanding. Frontier Plant Science 10: 318 https://doi.org/10.3389/fpls.2019.00318

Ning P, Fritschi FB, Li C. 2017. Temporal dynamics of post-silking nitrogen fluxes and their effects on grain yield in maize under low to high nitrogen inputs. Field Crops Research 204:249-259. https://doi. org/10.1016/j.fcr.2017.01.022

NIWA, 2021. Monthly climate summaries for December 2001 to the present. https://niwa.co.nz/ climate/monthly. Accessed 27 September 2021.

Plénet D, Lemaire G. 1999. Relationships between dynamics of nitrogen uptake and dry matter accumulation in maize crops. Determination of critical N concentration. Plant Soil 216: 65-82. https://doi.org/10.1023/A:1004783431055

Ross SM, Izaurralde RC, Janzen HH, Robertson JA, McGill WB. 2008. The nitrogen balance of three long-term agroecosystems on a boreal soil in western Canada. Agriculture, Ecosystem and Environment 127: 241-250. https://doi.org/10.1016/j. agee.2008.04.007

Tsimba R, Gunn T, Densley R, Millar J, Williams I, Clausen C. 2020. Quantification of nitrogen leaching losses under a typical maize silage cropping system. In: Christensen CL, Horne DJ, Singh R. Eds. Nutrient Management in Farmed Landscapes. http:// flrc.massey.ac.nz/publications.html. Occasional Report No. 33. Farmed Landscapes Research Centre, Massey University, Palmerston North, New Zealand. 11 pages. 
VSN International. 2021. Genstat for Windows 21st Edition. VSN International, Hemel Hempstead, UK. Zyskowski RF, Teixeira EI, Malcolm BJ, Johnstone PR, de Ruiter JM. 2016. Effectiveness of winter cover crops to reduce nitrogen leaching losses in cropping systems in Waikato, New Zealand. Agronomy New Zealand 46:109-119. https://www.agronomysociety. nz/files/2016_11._Winter_cover_crops_to_ reduce_N_leaching.p $\overline{\mathrm{d} f}$ 